UDC 1(100)(091)“13”

Submitted: 28.06 .2018

LBC 87.3(0)44

Accepted: 24.09 .2018

\title{
THEODORE METOCHITES' LOGOS 10 ON EDUCATION AND SOME ASPECTS OF THE NOTION OF CONTEMPLATION IN THE LATE WORKS OF HENRI BERGSON: ON REMINISCENCES ${ }^{1}$
}

\author{
Dmitriy I. Makarov \\ Urals State Mussorgsky Conservatoire, Ekaterinburg, Russian Federation
}

\begin{abstract}
Introduction. The research aim is to point to an interesting typological parallel between the notions of second, or passive, contemplation in late Byzantine philosopher Theodore Metochites (1270-1332) and Henri Bergson's Two Sources of Morality and Religion (1932).

Methods. The methodological basis of the work is the medieval and modern (Hegel's) notion of the unity of the philosophical process in the world. Traditional methods of cultural studies and the Geistesgeschichte (also known as 'intellectual history') are applied as well. At the same time we single out and confirm the basic opposition in the Byzantine culture between secular philosophy and Hesychasm, on the one hand, and certain convergences between Metochites' and Bergson's notions of a passive contemplation. Our sources are not confined with Metochites' and Bergson's texts, but include Theodore Adorno's Negative Dialectics, and, on the Byzantine side, Sophianos' Letter to Macarius, Metropolitan of Philadelpheia (ca. 1350) as well.

Analysis. In the 50th chapter of his 10th Logos On Education Metochites strongly criticized those who flew from the sensible reality, taking no active part in the mundane affairs, without reaching contemplation of the first principles of the Universe. They make just a stupid resignation from activity and get nothing instead, whereas the true contemplation always strives to see these principles. It is not a Hesychast prayer but scientific and philosophic analysis and rumination on the structure of the Universe. It is remarkable that, six centuries and a quarter later, the same strictures against such a kind of resignation reappeared again in the course of Bergson's polemics against those who could not make a choice between the two types of society, i.e., the closed one and the open one, staying halfway in between. We come to the conclusion that it would be advisable to look for further parallels between Late Byzantine and contemporary philosophy.

Results. There are certain typological parallels between the notion of contemplation in Metochites and Bergson, which should make us move further and look for ulterior resemblances between secular philosophy and anthropology of Byzantium and of the contemporary world. In the Appendix we publish the first to fifth chapters of On education in Russian translation performed by us.

Key words: Theodore Metochites, Henri Bergson, active contemplation, passive contemplation, cognition, active life, Hesychasm, Byzantine reminiscences in contemporary European philosophy.

Citation. Makarov D.I. Theodore Metochites' Logos 10 on Education and Some Aspects of the Notion of Contemplation in the Late Works of Henri Bergson: on Reminiscences. Vestnik Volgogradskogo gosudarstvennogo universiteta. Seriya 4, Istoriya. Regionovedenie. Mezhdunarodnye otnosheniya [Science Journal of Volgograd State University. History. Area Studies. International Relations], 2018, vol. 23, no. 5, pp. 48-59. (in Russian). DOI: https://doi.org/10.15688/jvolsu4.2018.5.4
\end{abstract}

$$
\text { УДК 1(100)(091)“13” }
$$

Дата поступления статьи: 28.06.2018

ББК 87.3(0)44 Дата принятия статьи: 24.09.2018

\section{ТРАКТАТ «ОБ ОБРАЗОВАННОСТИ» ФЕОДОРА МЕТОХИТА И НЕКОТОРЫЕ АСПЕКТЫ ПОНЯТИЯ СОЗЕРЦАНИЯ У ПОЗДНЕГО БЕРГСОНА: К ПРОБЛЕМЕ ПЕРЕКЛИЧЕК ${ }^{1}$}

\section{Дмитрий Игоревич Макаров}

Уральская государственная консерватории им. М.П. Мусоргского, г. Екатеринбург, Российская Федерация 
Аннотация. В 10-м слове (трактате «Об образованности», 1305) Феодор Метохит выделяет два вида созерцания - активное, направленное на познание природы и ее законов, и пассивное, которое останавливается на полпути между действием и познающим созерцанием. Лиц, предающихся этому второму виду созерцания, Метохит критикует за бездействие. Такое же разделение встречается и в последней книге Бергсона «Два источника морали и религии» (1932). И по Метохиту, и по Бергсону, настоящему философу не подобает замыкаться в башне из слоновой кости - но проявлять активную гражданскую и мировоззренческую позицию. Отмечается научный, а не исихастский характер созерцания, анализируемого Метохитом, и подчеркивается перспективность поисков дальнейших точек соприкосновения между новой и новейшей мыслью и концепциями византийского философа.

Ключевые слова: Феодор Метохит, Анри Бергсон, созерцание активное, созерцание пассивное, познание, деятельная жизнь, исихазм, переклички между византийской и новоевропейской философией.

Цитирование. Макаров Д. И. Трактат «Об образованности» Феодора Метохита и некоторые аспекты понятия созерцания у позднего Бергсона: к проблеме перекличек // Вестник Волгоградского государственного университета. Серия 4, История. Регионоведение. Международные отношения. - 2018. - Т. 23, № 5. C. 48-59. -DOI: https://doi.org/10.15688/jvolsu4.2018.5.4

Введение. Глубокие и всесторонние связи философско-этического учения Феодора Метохита (ок. 1270-1332) с идеями Филона Александрийского и Синезия Киренского стали предметом обстоятельного и всестороннего рассмотрения в работе Я. Полемиca [31]. Этому же ученому принадлежит и критическое издание «Слова на нравственные темы, или Об образованности», о котором пойдет речь [28]. В то же время вопрос об идейных перекличках Метохита с новой и новейшей европейской философией, насколько нам известно, пока не ставился (см. особенно: [20; 31; 30; 10, с. 32-33, 94, 118-119, 133-134; 8]). Вместе с тем рассмотрение данной проблематики сулит немало нового, особенно если мы выйдем за хронологические рамки Возрождения.

Методы. Как отмечал А. Гарсиа, говоря о трудах Синезия Киренского, уже в IV в. христиане понимали, что защищаемую ими мудрость необходимо соизмерять с миром, и стремились создать собственную пайдейю $[19$, S. 8] (вопрос о ее соотношениях с метохитовской, собственно, и ставит Я. Полемис). По Синезию, начатки философии - страсть к познанию. Философия независима от Бога: это - мирской разговор $[19, \mathrm{~S} .10]^{2}$, светский тип дискурса. Мы знаем и еще раз убедимся при чтении фрагментов, что такой подход был близок и Метохиту.

Для светской и духовной философии со времен Аристотеля важнейшая триада категорий (потенция - деятельность (энергия) энтелехия) включает в себя понятие «деятельность» ${ }^{3}$. Именно это мы видим и у Мето- хита: активную деятельность познающего ума, к которой византийский философ призывает адресата, он противопоставляет праздному и пассеистскому созерцанию (см. далее пример из 50-й главы трактата).

Неоднократно отмечалось, что понятие созерцания принадлежит к числу наиболее многозначных в истории мысли. На этот раз, как нам кажется, было бы полезно в поисках аналогий к аргументации Метохита обратиться к философии XX века - чтобы увидеть точную типологическую параллель в последней книге Анри Бергсона «Два источника морали и религии» (1932).

Анализ. Все наши знания, говорит Метохит в 50-й главе, мы почерпаем из опыта. Однако - в силу общего упадка культуры мы даже не в состоянии толком рассказать о том, что нам открывается в опыте [28, б. 206.50.6-12]. «Некоторые пошли еще дальше: основываясь на истинном опыте, общедоступном для всех, настолько презрели видимый мир, что сочли за лучшее не говорить о нем и вовсе ничего ${ }^{4}$, но впали в какое-то полнейшее безгласие ${ }^{5}$, довольствуясь одним лишь созерианием (здесь и далее курсив в цитатах наш. - Д. М.), да и ему не больно-то радуясь ${ }^{6}$ и будучи не в состоянии чего-либо добиться, руководствуясь им, потому что для большинства, как отмечалось раньше, больше созерцания ничего и нет. Так много ли проку в том, что кто-то уразумел людские бедствия глубже остальных, однако сам не миновал их (абсолютно добровольно или нет - другой вопрос) - точно так же, как и остальные? ${ }^{7}$ » [28, б. 206.50.12-22]. 


\section{ВИЗАНТИЙСКОЕ НАСЛЕДИЕ}

Метохит критикует тех, кто, отойдя от опытного познания чувственного мира, не дошел до познания сверхчувственного, а остановился в некоем промежуточном и пассивном созериании, каковое для Метохита неприемлемо (то раздолье, о котором идет речь в начале трактата (см. далее), предполагает активность мысли!).

Теперь обратимся к I главе «Двух источников морали и религии»:

«...единственная дорога ведет от действия, заточенного в замкнутом кругу, к действию, развертываемому в свободном пространстве, от повторения - к творчеству, от инфраинтеллектуального - к суперинтеллектуальному. Toт, кто останавливается между обоими действиями, непременно оказывается в области чистого созериания; не придерживаясь более одного и не достигнув другого, он естественно... осуществляет ту полудобродетель, каковой является отрешенность» [5, с. 68].

Бергсон адресует упрек тем, кто, отойдя от замкнутого, инфраинтеллектуального и несвободного действия, не дошел до разомкнутого (или открытого) и свободного, остановившись на «чистом созерцании». В обоих случаях созерцание оказывается той промежуточной сферой, к которой полувынужденно-полудобровольно прибегают люди пассивные, не желающие принимать активного участия ни в общественных, ни в культурных делах. Нам представляется, что мысль Метохита в данном вопросе, по сути, очень близка, если не тождественна, бергсоновской.

Бергсон, который разрабатывал понятие длительности и успешно пытался его синтезировать с понятием субстанции - активист. Чистое самосозерцание философии, сидение в башне из слоновой кости - пагубно для нее, как он подчеркивал: «Но если метафизика должна руководствоваться интуицией, если предмет интуиции - подвижность длительности, а длительность психологична по своей сути, то не выйдет ли у нас так, что мы заточим философию в самодовлеющем созерияани самой себя?» [16, р. 35].

Это понятие самодовлеющего созерцания, уводящего субъекта в сторону от активности в ее разных формах, по сути, тожде- ственно метохитовскому. Дискурс и тут - подчеркнуто светский, заставляющий вспомнить, предположим, критику Гуссерля у Адорно, хотя как раз последний имел основания отметить, что оба - Гуссерль и Бергсон - ушли из философии модерна «в традиционную метафизику» [1, с. 17].

Из других совпадений между Бергсоном и Метохитом обращает на себя внимание встречающаяся у обоих мысль о том, что недопустимо «основывать мораль на культе разума» $[5$, с. 95]. А.Г. Погоняйло прекрасно резюмировал эту линию в европейской культуре: «Культ разума иррационален. Он неразумен» [13, с. 52]. И потому - если вернуться к основным героям нашей работы - следует обратить пристальное внимание на представителей других сфер культуры. И прежде всего - на художников как на носителей творческого начала, чьи творения не менее (а порой и более) долговечны, чем написанные пером трактаты [8, с. 224-226]. В них может заключаться не меньше философских смыслов, чем в письменном тексте: «Из созерцания какогонибудь античного мрамора глазами подлинного философа может проистекать истина в более сконцентрированном виде, чем та, что рассеяна в том или ином философском трактате» $[16$, p. 38$]$.

Такое созерцание не идентично вышеупомянутому, проникнутому духом пассивности и резиньяции. Креативное созерцание (назовем его так) питается теми творческими эмоииями, которые направлены, по Бергсону, на действие и которые Ж. Делез называл «волевой интуицией» (цит. по: [22, p. 48-49]). Деятельный характер волевой интуиции, которая самим своим актом опровергает бездеятельность первого созерцания, подчеркивает и Л. Лолор в статье с говорящим заглавием «Новый взгляд на философию Бергсона» [22, p. 49]. В самом деле: «Человек может, конечно, мечтать или философствовать, но он должен вначале жить; безусловно, структура нашей психики порождена необходимостью сохранения и развития индивидуальной и социальной жизни» [5, с. 115].

Думается, что такой - опирающийся как на психологию, так и на метафизику - подход более отвечает духу нашей постсекулярной эпохи [15, с. 361$]$. 
По мере вчитывания в трактат Метохита мы увидим, что он, как и Бергсон, разграничивает два уровня созериания: первое, негативное, которое стало предметом критического анализа в данной статье, и второе позитивное и радостное, несущее светское блаженство «созерцательно-мусического бытия» (выражение Х.-Г. Бека) на лоне наук, поэзии и философии. Этот locus amoenus, «светский рай» поэзии и философии, был близок душе Метохита примерно так же, как и многим творцам новоевропейской культуры: Гете, Байрону, Пушкину, Батюшкову, Баратынскому...

То, чего недостает этому понятию по сравнению с мистическим идеалом исихастов и паламитов, и вообще православных мыслителей как XIV в., так и последующих эпох (которым Метохит по своим духовным устремлениям в принципе не противоположен) это нотки любви. Ведь «Тело Христово - Церковь - созидается чрез любовь, возможную только в постоянном пребывании в Духе Святом, Духе любви и, одновременно, Духе Господа Иисуса» [3, с. 43] (ср.: [12, с. 295]).

Нехватка этой составляющей этического и эстетического идеала становится особенно явственной при сопоставлении начальных глав трактата (да и всего трактата в целом) с произведениями православной литературы и эпистолографии XIV в., причем даже среднего уровня. Возьмем в качестве примера написанное в середине столетия (то есть лет через 40-50 после трактата Метохита) письмо Софиана митрополиту Филадельфийскому Макарию Хрисокефалу, достаточно видному богослову (его Слово на праздник Торжества Православия опубликовано [24] (ср.: [25, р. 347, 351])), в котором сквозит неподдельный восторг и благоговение перед сияющими добродетелями и мудростью учителя: «В самом деле, никто не будет настолько глуп и, скажем так, настолько далек от любви к прекрасному, чтобы не пробудиться душою и не вос-

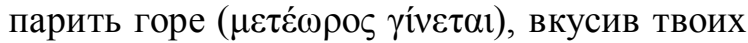
благодатей, о всех наилучший и божественнейший владыка» [26, S. 230.41-43].

Выводы. Вот этого благоговейного настроя и этого слоя церковной лексики нет у Метохита. Его феория не была исихастской. Еще один оборот из письма Софиана дает ясно почувствовать разницу между светским и духовным типами созерцания (которые разнятся как по модусу, так и по объекту: место Бога у исихастов и Софиана занимают studia humanitatis у Метохита). Сам я от слушания твоих слов настолько становлюсь лучше сам себя, продолжает Софиан, «...что всецело преображаюсь наилучшим

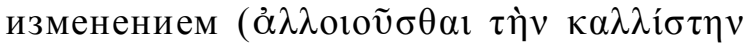
$\dot{\alpha} \lambda \lambda$ oí $\omega \sigma \iota v)$, становлюсь из одного - другим и всецело внимаю Богу, совершенно забыв обо всем земном» [26, S. 230.45-47].

В этой фразе употреблено важное выражение, принадлежащее к общему концептуальному уровню протопаламитской и паламитской антропологии (св. Никита Стифат, Никифор Влеммид, Феофан Никейский, Иоанн Кантакузин и др.) и описывающее реальное соединение обоженной души праведника с Богом [9, с. 283-290]. Но Софиана роднит с Феодором Метохитом тональность высказывания: есть веские основания полагать, что в его устах это все же - аллегория, а не описание живого исихастского опыта, подобного тому, что был, скажем, у Силуана Афонского и игумена Софрония (Сахарова). По отношению к духовной жизни в строго аскетическом смысле обоих наших византийских авторов XIV в. можно считать учениками. Тем любопытнее отметить как отличия, так и совпадения в оттенках мысли между представителями различных течений в поздневизантийском гуманизме.

В заключение статьи приведем свой перевод пролога трактата (гл. 1-5), выполненный по критическому изданию Я. Полемиca [28]. 


\title{
ПРИЛОЖЕНИЕ
}

\author{
Феодор Метохит. Слово на нравственные темы, или Об образованности \\ Главы 1-5 \\ Перевод со среднегреческого языка Д. И. Макарова
}

Глава 1

Уже не раз я пытался рассказать тебе кое-что о науках ( $\tau \tilde{\omega} \nu ~ \lambda о ́ \gamma \omega v)$ (в меру собственного знакомства с предметом и способности говорить о нем) и увещевать тебя заняться благим трудом - приложить все усилия к тому, чтобы ими овладеть; ведь прилежание в таком деле, да и сам процесс его освоения - не что иное, как истинное раздолье ( $\rho \alpha \sigma \tau \omega ́ v \eta v)$, любезное сердцу ${ }^{8}$. Но как только я намеревался за это взяться, со мной происходило то, что бывает с людьми, которые видят во снах отчетливую картину (őv $\alpha \rho)$ (cp.: Мф. 1, 20) того или иного занятия, которому предаются. Я размышлял над этим и уже вел беседы с тобой, но только мысленно ( $\mu \varepsilon ́ \chi \rho 1 ~ \tau \tilde{\omega} v \lambda о \gamma 1 \sigma \mu \tilde{\omega} v)$, на деле же не было возможности приступить к осуществлению задуманного, сколько бы я себя ни принуждал. Скорее, я занимался чем угодно, только не мог приступить к беседе с тобой (хотя и собирался говорить), ведь постоянно возникал то один, то другой предлог, который насильно уводил меня прочь от поставленной мною цели. Я был преисполнен житейских забот, уж не знаю, ни каковы они по сути, ни как о них рассказать, - совершенно

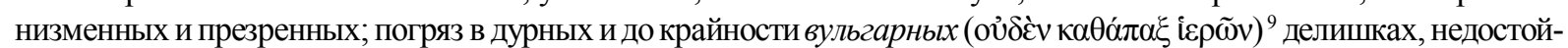
ных попечения, за которые сроду бы добровольно не взялся ни один достойный муж, знай он о них заране (чтоб они провалились самым ужасным образом!). Впрочем, это они, скорее, беспощадно сокрушают и раздробляют на мелкие кусочки ум любителя прекрасного, превращая орган мысли в неисчислимые мириады мерзостей.

\section{Глава 2}

И вот что еще мне представлялось в высшей степени затруднительным: если бы я даже и попытался заговорить с тобой о науках, оказалось бы, что я не подготовлен к такой беседе, поскольку давно уже оставил занятия ими, к которым некогда был привычен. «Богатство дается стараньем», - по словам поэта ${ }^{10}$. А произведение искусства, которое ежечасно не отделывают и оставляют без пристального попечения, неизбежно,

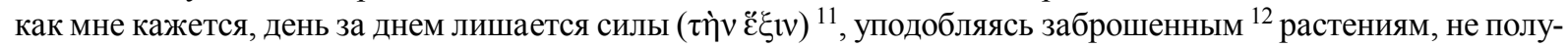
чающим надлежащего ухода ${ }^{13}$ : как эти растения не способны к росту ( оно безжизненно и не может быть доведено до совершенства ни одним разумным способом ${ }^{15}$.

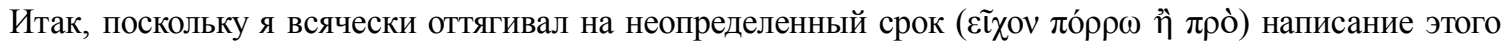
слова ${ }^{16}$ и работу над ним, то именно тебе, совершенно пренебрегавшему собой, суждено было обратить меня

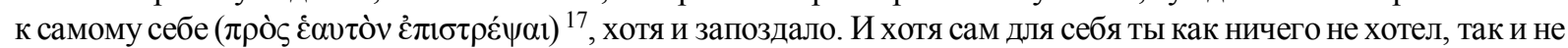
мог сделать, по отношению ко мне же оказался достаточно силен, чтобы высвободить меня от всяческих дел более многочисленных, нежели я мог тогда представить или настроиться. Ты же еще и сейчас не обрел себя, а меня - не знаю, как правильнее и выразиться: вернул либо ко мне же, либо, скорее, все-таки к себе.

И вот это избавление, которого я прежде не мог совершить сам, будучи вовсе лишен такой возможности, происходит благодаря тебе, и я надеюсь, что благодаря заботам о тебе смогу избавиться от всех прочих попечений. Итак, всецело, как я думаю, отойдя от своих дел и полностью расставшись с теми надеждами

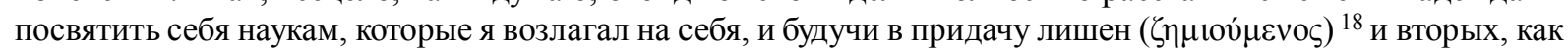
говорят, еще лучших, которые впоследствии в обилии питал относительно тебя, я тружусь в поте лица и, похоже, из-за тебя претерпеваю нечто ужасающее и уже невыносимое (хотя прежде полагал, что нет ничего страшного в том, чтобы предаваться такого рода чувствам). Вот это и стало, на мой взгляд, важнейшей причиной, которая понудила меня написать настоящее слово ( $\lambda$ ó $о \mathrm{v})$.

Впрочем, я вдобавок полагал, что если, чего доброго, стану пытаться в полной мере, как и тогда, восслав-

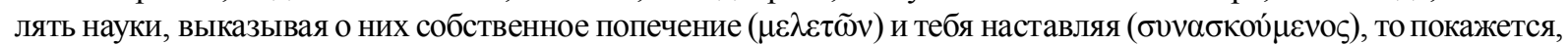
будто я претендую на то, чтобы ты и те, кто нас окружает, восхищались моими занятиями и чтобы вы и все люди вообще, в свою очередь, занимались ( $\sigma \pi о v \delta \alpha ́ \zeta \varepsilon v v){ }^{19}$ ими. Именно так обычно и поступает большинство людей, нахваливая ${ }^{20}$ всем подряд то, чем они занимаются сами, убеждая соглашаться с собой и внимать себе, как будто они - самые лучшие. В самом деле, одни прожужжат всем уши, расхваливая свои родные края, а также какие-то места и компании, другие - политический строй, третьи - тот или иной образ жизни, а остальные - все, что бы они для себя ни избрали и чем бы под действием той или иной необходимости ни занимались; взятые все вместе, эти бахвалы пробуждают в слушателях благие надежды, связанные с предметами своих занятий. 
Сейчас же я бы очень хотел, чтобы дела обстояли не так, как все случилось на самом деле (имеется в виду мой отход от занятий науками под влиянием того, с чем мне пришлось столкнуться). Пусть же никому не покажется, будто, взявшись все же прославлять то, чем с тех пор совершенно пренебрег, так что и оказался далече, я взялся за дело из жажды благодарности в свой адрес и в адрес своего дела, а не поневоле и будучи понуждаем необходимостью (так что в результате, скорее, и поддался уговорам). Разве не достоин я порица-

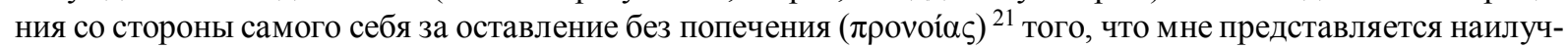
шим? С другой стороны, разве я не смогу выглядеть убедительным в твоих глазах, пытаясь убедить тебя в том, чем намеревался всерьез с тобой заняться и за пренебрежение чем считаю себя достойным упреков? Так вот, я скажу, ничего не утаивая, лишь столько, сколько задумал в начале, направляя и расширяя 22 данное слово, поскольку, как следует, приготовился не восхвалять науки и не говорить о них более того, чем они заслуживают. Потому что находятся ведь и те, кто считает должным уплачивать долг образованности

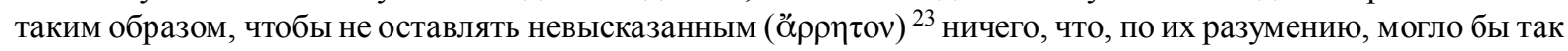

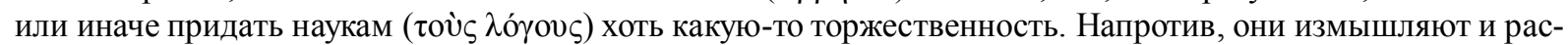
сказывают о науках всяческие небылицы, восхваляя, что есть сил, ученые занятия и, на мой взгляд, либо сознательно пренебрегая тем, что сами они бесконечно далеки от познания связанной с науками истины, и стремясь лишь возвысить предмет своих славословий, либо же столь неистовым стремлением к его прославлению вводя в заблуждение сперва себя, а там уже и остальных.

Несомненно, в обоих описанных случаях отход вышеупомянутых энкомиастов от добра и утрата ${ }^{24}$ должного не останутся без наказания и без подобающего воздаяния, как, впрочем, не пребудет непрощен-

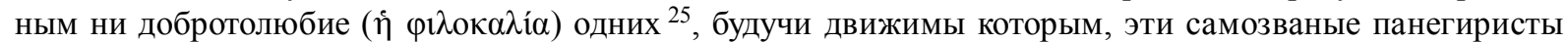

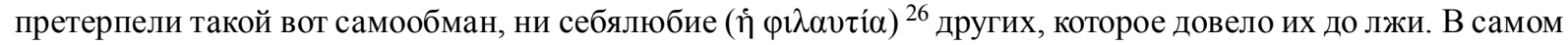
деле, себя ведь любят все и изо всех сил, сколь бы далеко это ни заходило. Похоже, себялюбие считается занятием столь невинным, что ради него одного всякий может спокойно решиться на что угодно. Себялюбцам хотелось бы, чтобы все, сделанное ими, было наилучшим или, по крайней мере, хотя бы казалось

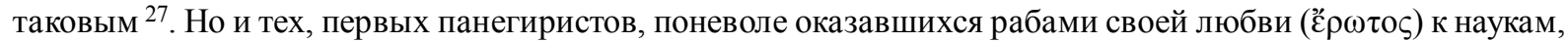
всякий готов понять и простить - более, чем в любом другом случае ${ }^{28}$, ведь эта страсть ( считается единственной, которой невозможно избежать и которая подчиняет себе абсолютно всех ( $\pi \alpha v \tau \alpha \dot{\pi} \alpha \alpha \sigma$ ßíaıvv). И их прощают, даже несмотря на то, что сами от себя они максимально сокрыли собственную неподготовленность и непредусмотрительность ${ }^{29}$ - пусть даже кто-нибудь заметит и поймет,

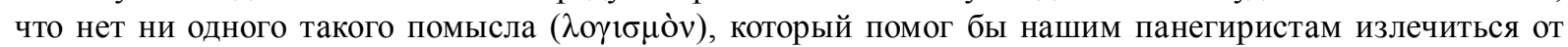
охватившей их болезни.

Впрочем, мне кажется, что обе стороны порой погрешают ${ }^{30}$ против рассматриваемого нами суждения, понуждая себя ( $\pi \rho \alpha \tau \tau o ́ \mu \varepsilon v o l){ }^{31}$ браться за ( $\left.\pi \varepsilon \rho \alpha i ́ v \varepsilon v\right)$ такие вещи, которые превосходят не только элементарное пособие для младших классов ${ }^{32}$, взыскуемое ими и составляющее предмет их устремлений, но даже

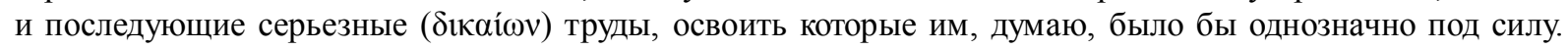
Сдается мне, что в своем безудержном и дерзком стремлении ко всякой выгоде и к любым видам превосходства они вредят всему предприятию в целом, уподобляясь тем из моряков, что, страдая большей по сравнению с остальными алчностью, постоянно догружают свое судно разного рода мелочью, в результате чего

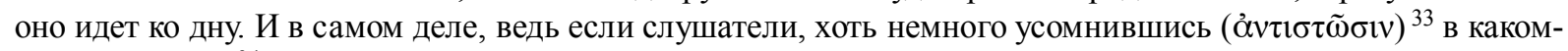
либо суждении ${ }^{34}$ по тому или иному поводу, заметят и поймут, что оно искажает (vобои̃v) истину, то тотчас -

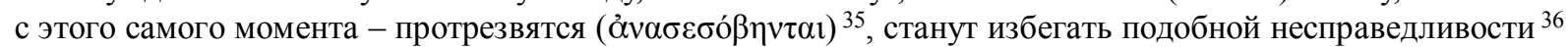
и уже не только перестанут доверять чему-либо подобному (и даже не снизойдут до него), но и скажут, что не без подозрений относятся ко всякой речи вообще и что не считают более возможным полагаться на тех,

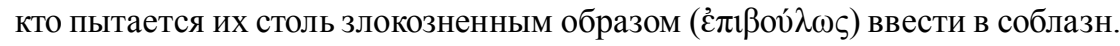

\section{Глава 4}

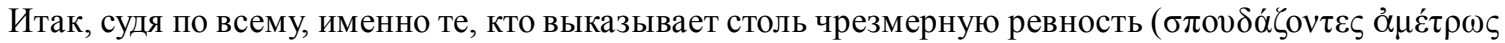
ỡ $\tau \varsigma \varsigma)$ об образовании ${ }^{37}$, больше всего и виновны в том, что многие разражаются бранью в его адрес

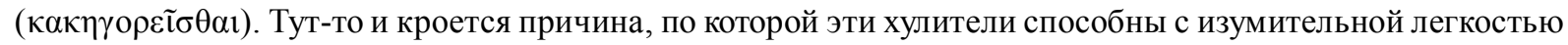
бесчинствовать, поносить науки ( ( $\dot{\alpha} v \alpha \gamma \kappa \alpha i ́ o v)$, предаваться худшим из всех пороков - зависти и необразованности ${ }^{38}$, уподобляясь тем, кто,

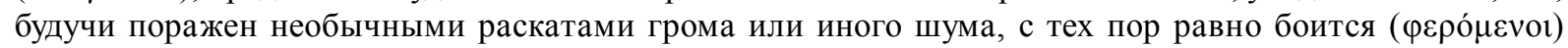
всего и вся. Они неистовствуют против наук ('А 
го, завидуют наукам как чему-то превосходящему их собственные возможности и лучшему, нежели то, чего они могут достичь по своей природе, и утверждают, будто нет ничего выдающегося 40 - такого, что можно было бы любить или стяжать. Но, весьма нам завидуя, противники образования упорно ${ }^{41}$ совершают противоположное тому, о чем говорят, тем самым убеждая нас, как думаю, в том, что они уподобляются тем, кто готов завидовать только наилучшему, и находятся в сильном разладе с самими собой. Ясно, что этим наши противники показывают, прежде всего, что собственные их дела находятся в бедственном положении, и изобличают собственную безграмотность. Они, на мой взгляд, направляют соб-

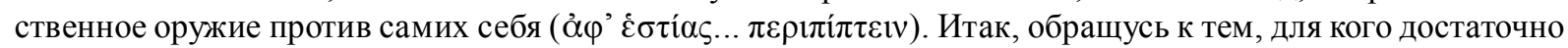
и краткого слова.

\section{Глава 5}

Да и стоит ли упоминать об этом большинстве - о тех, кто, подобно диким зверям, всю жизнь проводит, руководствуясь одним лишь чувством, вовсе не внимая более многочисленным и прекраснейшим частям души ${ }^{42}$, полностью пренебрегая как самими собой, так и природой? ${ }^{43}$ И ведь в ответ на такое изобилие, благой

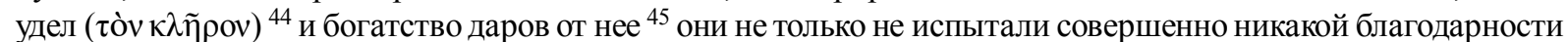
$(\chi \alpha ́ \rho v v)^{46}$, но даже и не знают, как этим всем воспользоваться! Вследствие этого наши оппоненты ${ }^{47}$, обладая столь несметными богатствами, уж не знаю, как и сказать - то ли добровольно, то ли поневоле, однако же, как мне видится, совершенно не изведали ни того, что им принадлежит, ни собственной сущности. Закопав в землю и скрыв там принадлежавшие им столь великие отцовские богатства ${ }^{48}$, они ввергли себя в рукотворную $(\chi \varepsilon є \rho-$

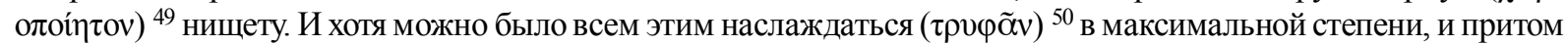

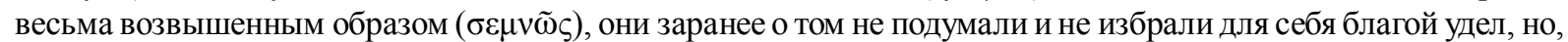
жалкие, умалив жизнь свою до вещей ничтожнейших и жалких, предаются непотребству. Будучи облечены умом, скрыли его в себе и больше к нему не прибегают - настолько, что и не ведают, сколь глубоко он зарыт в землю. Очернив и омрачив небосвод души, ничем не затененный в своей кристальной чистоте, прозрачность помыслов ${ }^{51}$ и рассудка ${ }^{52}$, окружили их стеной ${ }^{53}$, препятствующей проникновению какого бы то ни было луча

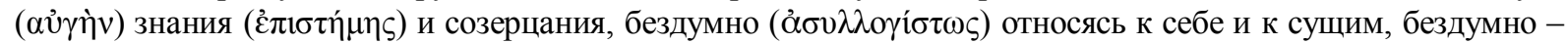

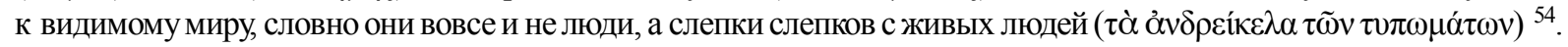
Будучи людьми лишь по форме ( понять, а из той, о которой слышат (если слышат), уже не в состоянии достигнуть чего-либо. Умом наши

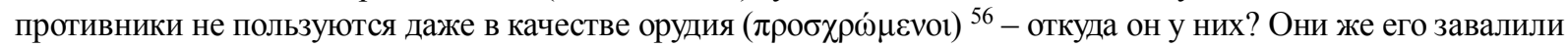

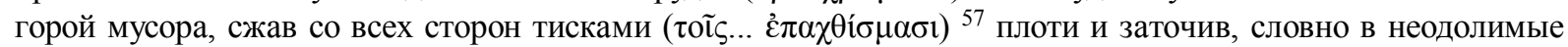

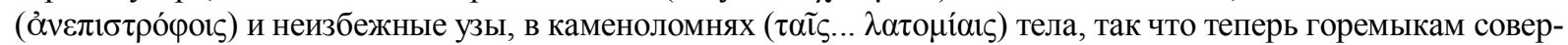

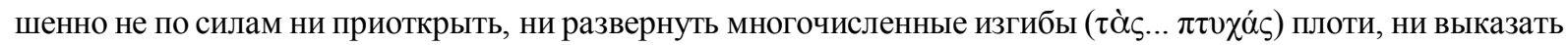

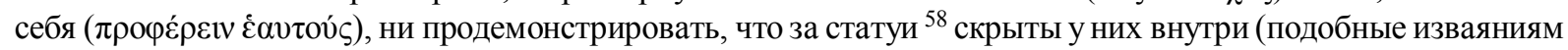
Гермеса - тем, что в древности стояли вдоль дорог) ${ }^{59}$. Напротив, все самое прекрасное они бесповоротно и намертво заточили внутри себя, словно в гробу, и живут, на мой взгляд, как будто удушив свою лучшую

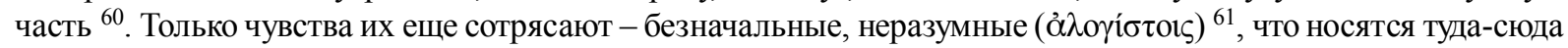
под влиянием любого встречного. Весь свой век эти люди бедствуют; если сравнить их жизнь с морем ${ }^{62}$, то можно сказать, что они задались целью затонуть в нем, не имея кормчего.

Впрочем, я полагаю, что те из купцов, что отправляются за моря на крупногабаритных судах, наряду с ними берут с собой в плавание и небольшие суденышки - чтобы так или иначе достичь земли, обеспечив себя водой, быстро и надежно удовлетворить любую нужду ( $\chi \rho \varepsilon i ́ \alpha v)$, возникающую от случая к случаю, и

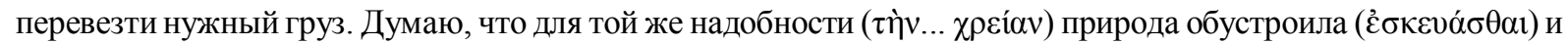
чувство. Если ум и мыслимые предметы (

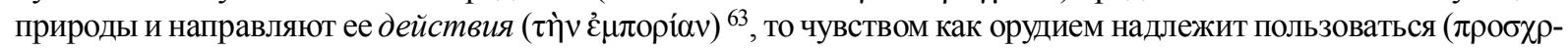
$\tilde{\eta} \sigma \theta \alpha \imath)$ лишь в той мере, которая приличествует наималейшей части всего ( $\tau$ ṽ $\pi \alpha v \tau$ ò $)$ ). А обращаемся мы к чувству затем, чтобы сделать хотя бы небольшой перерыв в интенсивной, но чрезвычайно утомительной

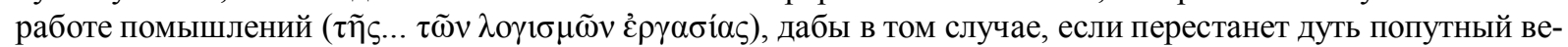

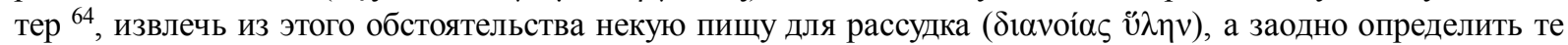

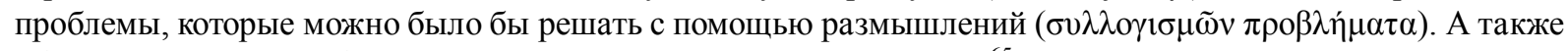
обрести нечто наподобие свежих и легких для усвоения стимулов ${ }^{65}$ для внутренне усердно совершаемой

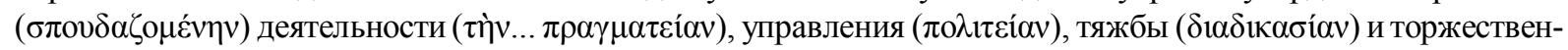

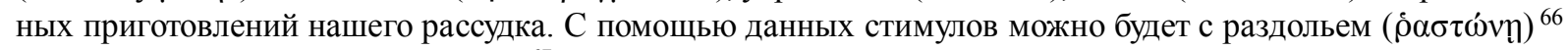

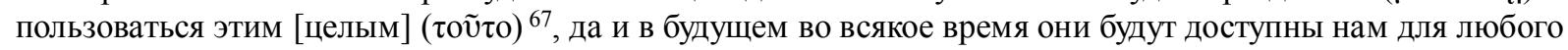
использования и смогут принести самую разнообразную пользу. 


\section{ПРИМЕЧАНИЯ}

${ }^{1}$ Исследование выполнено при поддержке гранта Российского научного фонда № 16-18-10202 «История логико-философских идей в византийской философии и богословии».

2 Размышляя над этим и аналогичными примерами, собранными в настоящей статье, приходится признать правоту А.Г. Погоняйло: философия - «все то, что люди называли и продолжают называть этим именем» $[13$, с. 43$]$.

${ }^{3}$ Ср. рассуждения Г. Каприева о базовых для византийской философии понятиях $\pi \rho \tilde{\alpha} \gamma \mu \alpha$ и $\pi \rho \tilde{\alpha} \xi ı s:$ [21, p. 4].

${ }^{4}$ Не обязательно это - монахи, можно предположить, что речь идет о светских философах антикизирующего толка, сторонников созерцательной

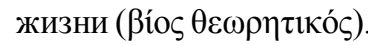

5 Или «невегласие» (если вспомнить словечко С.С. Аверинцева и В.В. Бибихина).

${ }^{6}$ Из этих слов видно, что речь идет о созерцании в чисто светском смысле, потому что духовное созерцание Бога, согласно традиции Пс.-Макария - Диадоха, несет с собой неотмирную радость.

7 Характерно, что в Византии такого рода пессимистическая антропология, напоминающая некоторые положения блаж. Августина о massa peccatorum, возникает на периферии религиозного дискурса.

${ }^{8} \mathrm{Cp}$. топоc locus amoenus. Это раздолье связано с действием, а не с отрешенным созерцанием - как мы только что видели, сходным (активистским) был и подход Бергсона.

9 Переводим ієро́ pacy [29, б. 159]. Здесь перед нами предстает категория вульгарности в эстетике и философии Метохита. Как видно из текста, вульгарное - то, что отвлекает от прекрасного, переключая на себя внимание субъекта помимо его воли.

${ }_{10}$ Гесиод. Труды и дни, стр. 412 (пер. В.В. Вересаева). У Я. Полемиса номер строки ошибочно указан как 42 [28, p. 5, n. 3]. Точнее было бы перевести вместе с Полемисом: «Благодаря старанью спо-

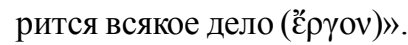

${ }^{11}$ Или «навыка» (так можно было бы перевести этот термин, если бы речь шла о человеке, а не о продукте его труда, который хранит в себе вложенную в него энергию). Энергийный подход греков к реальности не удивляет: так, согласно Плутарху («О судьбе»), даже судьба может пониматься как сущность - и как энергия. См., например: [17, p. 168].

12 Досл. «невозделываемым» (

13 Обращает на себя внимание органицизм эстетики Метохита: произведение искусства уподобляется возделываемому растению.
14 Интересное буквально-этимологическое прочтение слова «природа», которое могло бы заинтересовать Хайдеггера (вспомним рассуждения о природе как восхождении в «Гераклите»!).

15 Аристотелевское понятие энтелехии прямотаки просвечивает сквозь эти строки. Ср. у Т. Адорно: «Окончательное- это хорошо сделанное» [2, с. 292].

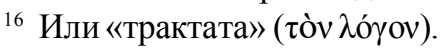

${ }^{17}$ Исихастский (у св. Григория Паламы) и философский термин, ставший популярным в наши дни благодаря идеям Фуко и его переводчиков и истолкователей. См.: [11; 14; 15, с. 117-119, 125-127; 13, c. 13-14, 24, 27].

${ }^{18}$ См.: [23, S. 643 (berauben)].

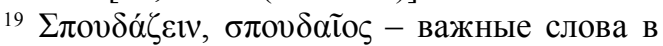
лексике трактата. См. далее.

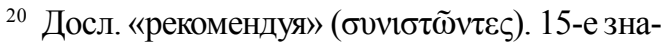
чение по Димитракосу [27, б. 6961].

${ }^{21}$ Прекрасный пример светского употребления важнейшего богословского термина.

${ }^{22}$ Или «пополняя», «прибавляя», «развертывая».

23 Термин мистики - и риторики. Здесь требуется именно «невысказанным» в смысле риторики, а не «несказанным» в смысле высокого богословия.

24 Досл. «недостижение».

25 Важнейшее представление античной и христианской аскетики и эстетики, отражающее идеал гармоничного развития человека.

${ }^{26}$ Важнейший термин аскетики, например, св. Иоанна Лествичника.

${ }^{27}$ В этих словах Метохит ставит важнейшую проблему: «Быть или казаться?» - или «Быть или иметь?» Вспомним труды Фромма, а также девиз Марины Цветаевой: «Mieux vaut être qu'avoir».

28 То есть если бы они занимались чем-то другим и неблаговидным.

29 То есть отсутствие заранее полученной соответствующей квалификации для ученых занятий (соответствующая идея встречается и в подчеркнуто интерпретирующем переводе Я. Полемиса).

${ }^{30}$ Или «уходят в сторону», «отклоняются».

31 6-е значение по LSJ («взыскивать», «требовать») в среднем залоге.

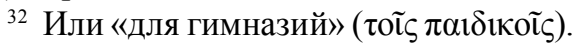

33 Я. Полемис переводит «критически отнесутся».

34 Полагаем, что "Нv в начале данной фразы соотносится с о̊коฑ́ выше перевели «суждения».

35 У Феофана Никейского встречается сино-

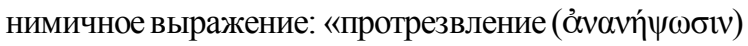
от ловушки диавольской» [18]. Ср.: [9, с. 193-196].

36 Вспомним платоновскую тему справедливости в «Государстве». Ложное познание морально предосудительно. 
37 Как по античным мудрецам, так и по Гегелю мера - наилучшее.

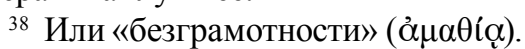

39 В переводе отражены различные семантические и контекстуальные грани значений неологизма $\alpha \lambda \lambda \gamma \varepsilon \dot{\varepsilon} \omega$, не зафиксированного (в отличие от

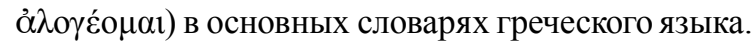
Форма 3 л. мн.ч. указывает на членов этого «большинства».

${ }^{40}$ Или «великого» $(\mu \varepsilon ́ \gamma \alpha)$.

41 Досл. «с ревностью». Наш перевод усиливает контрастность между словами и делами противников образования.

42 Связанным с умом.

43 Впоследней части фразы, как кажется, сходятся античная и христианская мудрость: толпа погрешает как против античных максим «Познай себя» и «Позаботься о себе», так и против античной же и христианской мысли о жизни согласно с природой (а не в греховном и противоестественном состоянии, связанном с последствиями грехопадения). Кроме того, мысль Метохита восходит к догматическому (в основе - аристотелевскому) различению природы и ипостаси. чении.

44 Слово употреблено в антикизирующем зна-

45 То есть от природы.

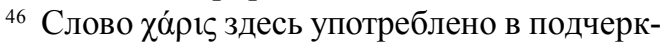
нуто антикизирующем смысле.

${ }^{47}$ Которые по своим характеристикам приближаются к das Man Хайдеггера.

48 Подразумевается Бог как Небесный Отец. Язык притчи о талантах (Мф. 25, 18. 24-30).

49 Прилагательное, подчеркнуто полемичное по отношению к христианскому термину

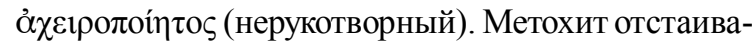
ет примат светского дискурса над религиозным. При этом слово «рукотворный» приближается по значению к «добровольный».

50 Этот глагол употребляется в высоких богословских контекстах (описание бытия первородных до грехопадения) у Григория Паламы и у других авторов (ср. евр. Эдем - «наслаждение»).

${ }^{51}$ Или «помышлений» $(\tau \tilde{\omega} v \lambda$ 위 $\mu \tilde{\omega} v)$.

52 О влиянии Платона и особенно Филона на трактовку этой темы см. примеч. 8 Я. Полемиса: $[28, \sigma .17,19]$.

53 Образ Филона, излюбленный Метохитом (примеч. 9 Я. Полемиса: [28, б. 19]).

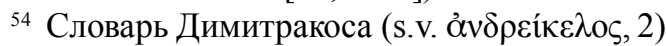

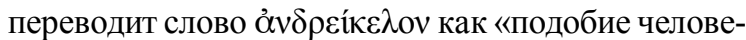
ка» (Т. 'А. $\Sigma .482$ ), семантика слова $\tau \hat{\pi} \pi \omega \mu \alpha$ также вполне прозрачна.

55 Предполагаем, что ๆิv [28, $\sigma .18 .5]$ относится к $\tilde{\eta} \varsigma \varphi v ́ \sigma \varepsilon \omega \varsigma$ [28, б. 16.1].

${ }^{56}$ Согласно Метохиту, ум не может быть орудием - он представляет собой цель саму по себе, верховную цель развития природы и ее деятельности [28, б. 20.11-12]. Соответственно, в данной фразе представителям толпы дается вдвойне пейоративная характеристика - то есть даже в таком усеченном виде, не сообразуясь с общим логосом ума, а лишь при решении конкретных жизненных задач, они и то не умеют пользоваться умом. Ср. текст в конце этой главы.

57 Точнее, «давлениями», «сжатиями», «обременениями». Согласно данным LBG, слово $\dot{\varepsilon} \pi \alpha ́ \chi \theta \imath \sigma \mu \alpha$ в поздневизантийской литературе встречается только у Метохита [23, S. 556].

${ }^{58}$ Идеал мудреца и прекрасного человека как статуи, восходящий (после классической античности) к Клименту Александрийскому и Пс.-Дионисию Ареопагиту (гностик как статуя)... Как известно, еще Поликлет (по сообщению Галена) назвал свою статую Каноном. См., например: [4, с. 590].

${ }^{59}$ Cp.: Plato. Symp. 215 b. Примеч. 11 Я. Полемиса: [28, б. 19].

${ }^{60}$ О сходстве этой мысли с Иосифом Философом (Фессалоника, конец XIII - начало XIV в.) см. примеч. 12 Я. Полемиса: [28, б. 19].

${ }^{61}$ Мысль Филона (О Десятисловии..., 67-68). Примеч. 13 Я. Полемиса: [28, б. 21].

62 Море в византийской письменности - как церковный образ (например, в 12-й гомилии св. Василия Великого, а также в гомилиях св. Григория Паламы: PG. 151. 157B, 408C), так и топос светской гуманистической литературы [6;7].

${ }^{63}$ И вновь, как и у Плутарха, и у св. Григория Паламы, мы видим акцент на деятельностном аспекте реальности, на $\pi \rho \tilde{\alpha} \xi ı$, говоря словами Г. Каприева [21].

${ }^{64}$ О параллелях из самого Метохита см. примеч. 14 Я. Полемиса: [28, б. 21-23].

65 Досл. «питательных средств» ( $\pi \dot{\varepsilon} \mu \mu \alpha \tau \alpha)$.

${ }^{66}$ О котором шла речь в 1 главе: [28, $\left.\sigma .2 .6\right]$.

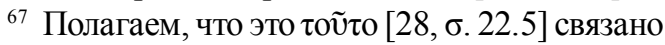

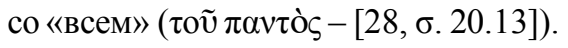

\section{СПИСОК ЛИТЕРАТУРЫ}

1. Адорно, Т. В. Негативная диалектика / Т. В. Адорно ; пер. с нем. Е. Л. Петренко. - М. : Научный мир, 2003. - 374 с.

2. Адорно, Т. В. Философия новой музыки / Т. В. Адорно ; пер. с нем. Б. Скуратова. - М. : Логос, 2001.-352 c.

3. Арранц, М. Избранные сочинения по литургике. Т. І. Таинства византийского Евхология / М. Арранц. - Рим ; М. : Институт теологии, философии и истории Св. Фомы, 2003. - 616 с. (Bibliotheca Ignatiana).

4. Асмус, В. Ф. Эстетика классической Греции / В. Ф. Асмус // Собрание сочинений (в семи 
томах). Т. 2. Античная философия и эстетика / В. Ф. Асмус. - М. : УРСС, 2014. - 842 с.

5. Бергсон, А. Два источника морали и религии / А. Бергсон ; пер. с франц. А. Б. Гофмана. М. : Канон+, 1994. - 384 с. - (История философии в памятниках).

6. Каждан, А. П. «Корабль в бурном море». К вопросу о соотношении образной системы и исторических взглядов двух византийских писателей / А. П. Каждан // Из истории культуры Средних веков и Возрождения. - М. : Наука, 1976. - С. 3-16.

7. Кущ, Т. В. На закате империи: интеллектуальная среда поздней Византии / Т. В. Кущ. - Екатеринбург : Изд-во Уральского ун-та, 2013. - 456 с.

8. Макаров, Д. И. Исихазм и внимание к классическому прошлому: две заметки о чертах своеобразия византийского гуманизма XIII-XIV вв. / Д. И. Макаров // Диалог двух культур Востока и Запада через призму единства и многообразия : Древний мир, Средневековье, Новое и Новейшее время / отв. ред. В. Н. Вдовин. - Алматы ; Екатеринбург : Ин-т философии, политологии и религиоведения Комитета науки министерства науки и образования Республики Казахстан, 2018. - С. 217-229.

9. Макаров, Д. И. Мариология Феофана Никейского в контексте византийской богословской традиции VII-XIV вв. : С приложением переводов трактатов Никифора Влеммида и св. Каллиста I Константинопольского / Д. И. Макаров. - СПб. : Изд-во Олега Абышко, 2015. - 416 с. - (Библиотека христианской мысли).

10. Медведев, И. П. Византийский гуманизм XIV-XV вв. / И. П. Медведев. - СПб. : Алетейя, 1997. 342 с. - (Византийская библиотека).

11. Мейендорф, И., прот. Тема «обращения к себе» в паламитском учении XIV столетия / И. Мейендорф ; пер. с фр. У. С. Рахновской // Пасхальная тайна : Статьи по богословию / И. Мейендорф. М. : Изд-во Православного Свято-Тихоновского гуманитар. ун-та, 2013. - С. 569-585.

12. Осэрр, И. Богословие монашеской жизни у св. Иоанна Лествичника / И. Осэрр ; пер. с фр. Г. В. Вдовиной // Символ. - 2007. - Т. 52. - С. 277-306.

13. Погоняйло, А. Г. Мышление и созерцание. Материалы к лекциям по истории философии / А. Г. Погоняйло. - СПб. : Наука, 2017. - 584 с. (Слово о сущем ; 111).

14. Фуко, М. Герменевтика субъекта / М. Фуко ; пер. с фр. А. Г. Погоняйло. - СПб. : Наука, 2007. $677 \mathrm{c}$.

15. Хоружий, С. С. Социум и синергия: колонизация интерфейса / С. С. Хоружий. - Казань : Казанский инновационный ун-т им. В. Г. Тимирясова (ИЭУП), 2016. - 452 c.

16. Bergson, H. Memoria y vida. I. La duración y el método. Fragm. 17 / H. Bergson // Memoria y vida.
Textos escogidos por G. Deleuze / H. Bergson ; trad. M. Armiño. - Madrid : El Libro de Bolsillo : Alianza Editorial, 1977. - $164 \mathrm{p}$.

17. Cochrane, Ch. N. Christianity and Classical Culture. A Study of Thought and Action from Augustus to Augustine / Ch. N. Cochrane. - London ; N. Y.; Toronto : Oxford Univ. Press, 1944. - 523 p.

18. Ejusdem [Theophanis] Epistula III/ Theophanus Nicaenus // Patrologiae cursus completus. Series graeca. Vol. 150.- Paris: Apud J.-P. Migne, 1865. -349p.

19. Garzya, A. Synesios' Dion als Zeugnis des Kampfes um die Bildung im 4. Jahrhundert nach Christus / A. Garzya // Jahrbuch der Österreichischen Byzantinistik. - 1973. - Bd. 22. - S. 1-14.

20. Hunger, H. Theodoros Metochites als Vorläufer des Humanismus in Byzanz / H. Hunger // Byzantinische Zeitschrift. - 1952. - Bd. 45. - S. 4-19.

21. Kapriev, G. Philosophy in Byzantium and Byzantine Philosophy / G. Kapriev // The Ways of Byzantine Philosophy / ed. M. Knežević. - Alhambra, CA : Sebastian Press, 2015. - P. 1-8.

22. Lawlor, L. Bergson Revisited / L. Lawlor // Symposium: Canadian Journal of Continental Philosophy / Revue canadienne de philosophie continentale. -2006. - Vol. 10/ 1. - P. 35-52.

23. Lexikon der byzantinischen Gräzität. Bd. 3 / Hrsg. E. Trapp. - Wien : Verl. d. Österr. Akad. d. Wiss., 1999. $-648 \mathrm{~S}$.

24. Macario Crisocefalo (1300-1382). L'omelia sulla festa dell'Ortodossia e la basilica di S. Giovanni di Filadelfia / ed. G. Passarelli. - Roma : Pontificio Ist. Orientale, 1980.-216 p.-(OCA ; 210).

25. Makarov, D. I. In terram visionis: The Image of Abraham in Nicephorus Choumnus' Homily on the Transfiguration (BHG 1998w) / D. I. Makarov // Scrinium. - 2017. - Vol. 13. - P. 338-360.

26. Walther, R. Ein Brief an Makarios, den Metropoliten von Philadelpheia / R. Walther // Jahrbuch der Österreichischen Byzantinistik. -1973. Bd. 22. - S. 219-232.

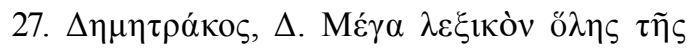

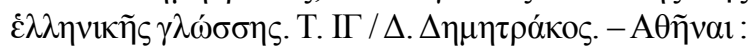

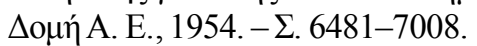

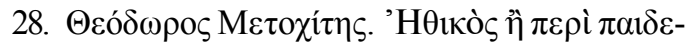

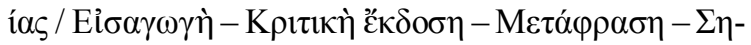

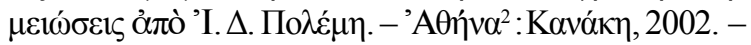

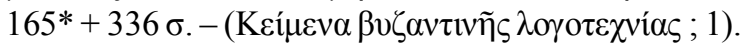

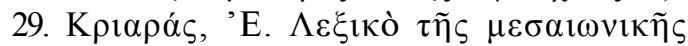
$\varepsilon \lambda \lambda \eta \nu 1 \kappa \tilde{\eta} \varsigma \delta \eta \mu \omega ́ \delta$ ov $\gamma \rho \alpha \mu \mu \alpha \tau \varepsilon i ́ \alpha \varsigma, 1100-1669$. T. Z'

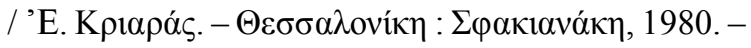
$414 \sigma$.

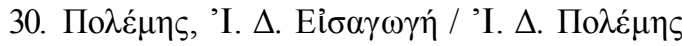

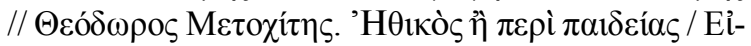

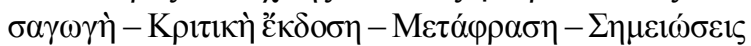

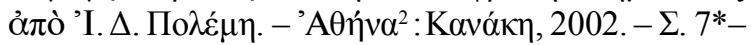

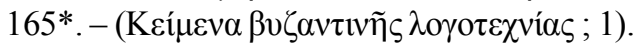




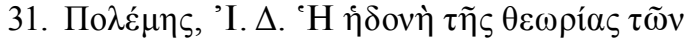

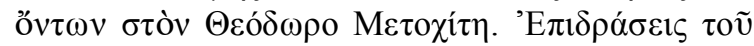

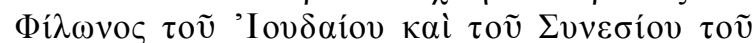

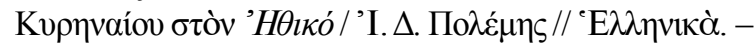
1999. - T. 49/2. - ¿. 245-275.

\section{REFERENCES}

1. Adorno T.V. Negativnaya dialektika [Negative Bialectics]. Moscow, Nauchnyy mir Publ., 2003. 374 p. (in Russian).

2. Adorno T.V. Filosofiya novoy muzyki [Philosophy of the New Music]. Moscow, Logos Publ., 2001. 352 p. (in Russian).

3. Arranz M. Izbrannye sochineniya po liturgike. T. 1. Tainstva vizantiyskogo Evchologiya [Selected Articles on Liturgiology. Vol. I. The Sacraments of the Byzantine Euchologion]. Rome; Moscow, Institut geologii, filosofii i istorii Sv. Fomy Publ., 2003. 616 p. (Bibliotheca Ignatiana) (in Russian).

4. Asmus V.F. Estetika klassicheskoy Gretsii [The Classical Greek Aesthetics]. Asmus V.F. Sobranie sochineniy (v semi tomakh). T. 2. Antichnaya filosofiya i estetika [Collected Works (in 7 vols). Vol. 2. Antique Philosophy and Aesthetics]. Moscow, URSS Publ., 2014. 842 p. (in Russian).

5. Bergson A. Dva istochnika morali i religii [Two Sources of Morality and Religion]. Moscow, Kanon+ Publ., 1994. 384 p. (History of philosophy in monuments). (in Russian).

6. Kazhdan A.P. «Korabl v burnom more». $\mathrm{K}$ voprosu o sootnoshenii obraznoy sistemy i istoricheskikh vzglyadov dvukh vizantiyskikh pisateley ["A Ship in a Lumpy Sea". A Contribution to the Problem of the Interrelationship between the Imagery and the Historical Views of the Two Byzantine Writers]. V.A. Karpushin, ed. Iz istorii kultury Srednikh vekov $i$ Vozrozhdeniya [From the Cultural History of the Middle Ages and the Renaissance]. Moscow, Nauka Publ., 1976, pp. 3-16 (in Russian).

7. Kushch T.V. $N a$ zakate imperii: intellektualnaya sreda pozdney Vizantii [At the Sunset of the Empire: The Intellectual Milieu of the Late Byzantium]. Ekaterinburg, Izd-vo Uralskogo universiteta, 2013. 456 p. (in Russian).

8. Makarov D.I. Isikhazm i vnimanie $\mathrm{k}$ klassicheskomu proshlomu: dve zametki o chertakh svoeobraziya vizantiyskogo gumanizma XIII-XIV vv. [Hesychasm and the Attention to the Classical Past. Two Notes on Some Peculiarities of the Byzantine Humanism of the Thirteenth and Fourteenth Centuries]. Vdovin V.N., ed. Dialog dvukh kultur Vostoka $i$ Zapada cherez prizmu edinstva i mnogoobraziya: Drevniy mir, Srednevekove, Novoe i Noveyshee vremya [The Dialogue between the Two Cultures of the East and West through the Prism of Unity and Diversity: Ancient World, Middle Ages, New and Contemporary Time]. Almaty; Ekaterinburg, Institut filosofii, politologii i religiovedeniya Komiteta nauki ministerstva nauki i obrazovaniya Respubliki Kazakhstan Publ., 2018, pp. 217-229. (in Russian).

9. Makarov D.I. Mariologiya Feofana Nikeyskogo $v$ contekste vizantiyskoy bogoslovskoy traditsii VII-XIV vv. S prilozheniem perevodov traktatov Nikifora Vlemmida i sv. Kallista I Konstantinopolskogo [Theophanes' of Nicaea Mariology Within the Context of Byzantine Theological Tradition of the $7^{\text {th }}-14^{\text {th }}$ Centuries. With an Appendix of the Translations of the Treatises by Nicephorus Blemmydes and Callistus I of Constantinople]. Saint Petersburg, Izd-vo Olega Abyshko Publ., 2015. 416 p. (The Library of Christian Thought). (in Russian).

10. Medvedev I.P. Vizantiyskiy gumanizm XIV$X V v v$. [Byzantine Humanism of the $7^{\text {th }}-15^{\text {th }}$ Centuries]. Saint Petersburg, Aletheia Publ., 1997. 342 p. (The Byzantine Library) (in Russian).

11. Meyendorff J., prot. Tema «obrashcheniya $\mathrm{k}$ sebe» v palamitskom uchenii XIV stoletiya [The Theme of the "Conversion to One's Self" in the Palamite Doctrine of the Fourteenth Century]. Meyendorff J., prot. Paskhalnaya tayna. Stati po bogosloviyu [The Paschal Mystery. Theological Articles]. Moscow, Izd-vo Pravoslavnogo Svyato-Tikhonovskogo Gumanitarnogo universiteta Publ., 2013, pp. 569-585. (in Russian).

12. Hausherr I. Bogoslovie monasheskoy zhizni u sv. Ioanna Lestvichnika [Theology of the Monastic Life in St. John of the Ladder]. Simvol, 2007, vol. 52, pp. 277-306. (in Russian).

13. Pogonyaylo A.G. Myshlenie i sozertsanie. Materilay $k$ lektsiyam po istorii filosofii [Thought and Contemplation. Materials for the Lectures on the History of Philosophy]. Saint Petersburg, Nauka Publ., 2017. 584 p. (The word on things in existence; 111). (in Russian).

14. Foucault M. Germenevtika subekta [Hermeneutics of the Subject]. Saint Petersburg, Nauka Publ., 2007. 677 p. (in Russian).

15. Khoruzhiy S.S. Sotsium i sinergiya: kolonizatsiya interfeysa [Society and Synergy: The Colonization of Interface]. Kazan, Kazanskiy innovatsionnyy universitet imeni V.G. Timiryasova (IEUP) Publ., 2016. 452 p. (in Russian).

16. Bergson H. Memoria y vida. I. La duración y el método. Fragm. 17. Bergson H. Memoria y vida. Textos escogidos por G. Deleuze. Madrid, El Libro de Bolsillo; Alianza Editorial, 1977. 164p.

17. Cochrane Ch.N. Christianity and Classical Culture. A Study of Thought and Action from Augustus to Augustine. London; N.Y.; Toronto, Oxford University Press, $1944.523 \mathrm{p}$. 
18. Ejusdem [Theophanis] Epistula III. Patrologiae cursus completus. Series graeca. Vol. 150. Paris, apud J.-P. Migne, 1865.349 p.

19. Garzya A. Synesios' Dion als Zeugnis des Kampfes um die Bildung im 4. Jahrhundert nach Christus. Jahrbuch der Österreichischen Byzantinistik, 1973, vol. 22, pp. 1-14.

20. Hunger H. Theodoros Metochites als Vorläufer des Humanismus in Byzanz. Byzantinishe Zeitschtift, 1952, vol. 45, pp. 4-19.

21. Kapriev G. Philosophy in Byzantium and Byzantine Philosophy. M. Knežević, ed. The Ways of Byzantine Philosophy. Alhambra, CA, Sebastian Press, 2015, pp. 1-8.

22. Lawlor L. Bergson Revisited. Symposium: Canadian Journal of Continental Philosophy/Revue canadienne de philosophie continentale, 2006, vol. 10/1, pp. 35-52.

23. Trapp E., ed. Lexikon der byzantinischen Gräzität. Wien, Verlag der Österreichische Akademie der Wissenschaften, 1999, vol. 3. 648 p.

24. Passarelli G., ed. Macario Crisocefalo (13001382). L'omelia sulla festa dell'Ortodossia e la basilica di S. Giovanni di Filadelfia. Roma, Pontificio Istituto Orientale, 1980.216 p. (OCA; 210).

25. Makarov D.I. In terram visionis: The Image of Abraham in Nicephorus Choumnus' Homily on the Transfiguration (BHG 1998w). Scrinium, 2017, vol. 13, pp. 338-360.
26. Walther R. Ein Brief an Makarios, den Metropoliten von Philadelpheia. Jahrbuch der Österreichischen Byzantinistik, 1973, vol. 22,pp. 219-232.

27. Demetrakou D. Mega lexikon olès tès ellēnikēs glossēes [A Comprehensive Dictionary of the Greek Language]. Athens, Domē Б. E. Publ., 1954, vol. 13, pp. 6481-7008. (in Greek).

28. Polemis I.D., ed. Theodoros Metochitess. $\bar{E}$ thikos e peri paideias [A Treatise on the Ethical Problems, or On Education], Athens, Kanake Publ., $2002.165^{*}+336$ p. (Keimena byzantinēs logotechnias [Texts of Byzantine Literature]; 1). (in Greek).

29. Kriara E. Lexiko tēs mesaionikēs ellēnikēs demodous grammateias, 1100-1669 [A Dictionary of the Medieval Greek Popular Literature, 1100-1669]. Thessalonikē, Sfakianakē Publ., 1980, vol. 7. 414 p. (in Greek).

30. Polemis I.D. Eisagogē [Introduction]. Polemis I.D., ed. Ethikos e peri paideias [A Treatise on the Ethical Problems, or On Education]. Athens, Kanake Publ., 2002, pp. 7*-165*. (Texts of Byzantine Literature; 1). (in Greek).

31. Polemis I.D. Ē ēdonē tēs theōrias tōn ontōn ston Theodōro Metochitē. Epidraseis tou Philōnos tou Ioudaiou kai tou Synesiou tou Kyrēnaiou ston Ēthiko [A Pleasure of the Contemplation of Beings in Theodore Metochites. The Impact of Philo the Jew and Synesios of Cyrene]. Ellēnika, 1999, vol. 49/2, pp. 245-275. (in Greek).

\section{Information about the Author}

Dmitriy I. Makarov, Doctor of Sciences (Philosophy), Associate Professor, Professor and Head of Department of General Humanities, Urals State Mussorgsky Conservatoire, Prosp. Lenina, 26, 620014 Ekaterinburg, Russian Federation, dimitri.makarov@mail.ru, https://orcid.org/0000-0002-3902-6190

\section{Информация об авторе}

Макаров Дмитрий Игоревич, доктор философских наук, доцент, профессор и зав. кафедрой общих гуманитарных дисциплин, Уральская государственная консерватория им. М. П. Мусоргского, просп. Ленина, 26, 620014 г. Екатеринбург, Российская Федерация, dimitri.makarov@mail.ru,https://orcid.org/0000-0002-3902-6190 